\title{
Why Is It That? Ironies, Paradoxes, and Subtleties
}

While I was serving as the founding editor of Library Administration $\mathcal{E}$ Management, I ran a brief column on "Why Is It That?" In the column I posed various questions to stimulate thinking on why it is that librarians/information professionals place emphasis on or deemphasize particular practices or values and continue to perform specific functions or services. The response from the readership brought some interesting answers to the questions and some of the comments were expanded into journal articles.

Like many other professionals, academic librarians tend to do some of the same things year after year without asking "Why are we doing this?" We simply do not do enough critical and alternative thinking. Notwithstanding the unprecedented rate of change we are experiencing in academic libraries, we prefer to remain cocooned in comfort. Transformations bring with them uncertainty and a degree of pain. While remaining in the comfort zone or making major changes, we promote more ironies and paradoxes.

\section{Contradictions}

Policies and practices in academic libraries/ibrarianship are laden with contradictions and inconsistencies. There are far too many of them for me to include in this space. However, some are quite obvious.

Isn't it interesting how we continue to measure the effectiveness of an academic library by the size of its inventory? The Association of Research Libraries (ARL) promotes this practice by its annual ranking of mem-

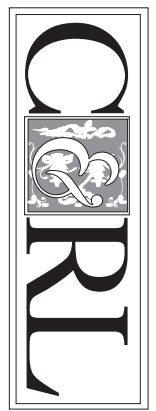
ber libraries based on five variables (volumes held, volumes added, current serials, total expenditures, and number of professional and support staff). The importance given to the five variables could possibly hinder the effectiveness of a given library, and it certainly can dampen the enthusiasm for promoting creative ways to meet the scholarly needs of students and faculty. If an ARL library director moves a significant amount of funds from one or more of the five variables, the library could drop in rank; subsequently, faculty and administrators will want to know why "their" library is dropping in the ARL ranking. ARL has done well in gathering supplementary statistics and offering a disclaimer that the quantitative rank order should not be used as a measure of library quality. However, the fact remains that if the library drops in its rank as a result of diverting funds from the serials budget to acquire more electronic multimedia material, the library will be perceived as being of less quality by the local and scholarly community. The refusal of ARL to count microforms as one of the variables used in the ranking remains puzzling. Ironic, but true!

\section{Paradoxes}

Faculty status and rank for academic librarians have always been full of ironies and paradoxes. Librarians working in institutions of higher education have a very difficult time measuring up to the faculty in other disciplines regarding re- 
search and publication. And they will continue to face this challenge as long as they are required to work a full week without any time off for these pursuits. Even those librarians who get some time for research and writing do not feel they can measure up to the performance of other faculty who have much more time for these scholarly endeavors. I have heard presidents, vice-presidents for academic affairs, and faculty comment about the lack of scholarly content, research, and methodology in the work produced by library faculty. With the "doing more with less" phenomenon becoming more common, I predict that it will be yet more difficult for library faculty to engage in the rigors of scholarly research. However, we should not give up faculty status and rank; such a loss would have a serious impact on academic librarianship. Some of my friends disagree vehemently with my stance on this issue. Moreover, one responsibility of an academic library leader is to provide the time and resources necessary for library faculty to produce scholarly work of the highest quality. More deans of colleges and schools are giving their assistant professors one semester off to conduct research and prepare for the six-year tenure review. How many directors provide the same opportunity for their library faculty?

\section{Interdependence}

The days are over when each library can have its own crown jewels. With acquisitions budgets barely able to keep up with inflation, there has to be more interdependent collection building. Some smaller libraries, particularly smaller ARL libraries, are not enthusiastic about engaging in interdependent collection development with the larger ARL libraries. One rationale given is based on the concept that if these smaller libraries do not build their local collections in a significant way, they will never become "great research librar- ies." The reality is they will probably never reach this level of achievement, despite modest gains in the acquisitions budget. Also, for various reasons, it is much easier to share electronic collections and databases than to cooperate in building paper collections that will be shared extensively among institutions.

Business leaders view institutions of higher education as havens for "process." Academic librarians, for example, tend to equate meetings with communication improvement. I believe a well-organized and executed

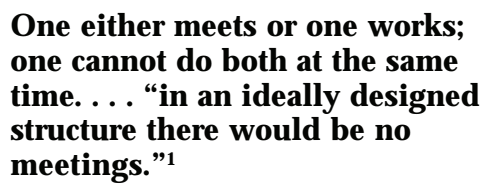

meeting will enhance communication. However, does one need a meeting to improve the communication process? Possibly not. The primary product of the ALA has been described as process; if one wants to see how process takes priority over product, just visit an ALA Council meeting. Peter Drucker believes that meetings are by definition a concession to deficient organization. One either meets or one works; one cannot do both at the same time. He goes on to state that "in an ideally designed structure there would be no meetings." ${ }^{11}$ Nevertheless, I confess to attending or holding my share of meetings, and that we academic librarians will continue to meet-for whatever reason!

\section{A Different View}

Now is the best time in our civilization to work in academic libraries. Our future work life will continue to be filled with contradictions and inconsistencies. It will be in accordance with that cliche, "the more we change, the more we remain the same." The enabling technology has added substantive value to our 
place in our institutions, and it is dramatically changing the way the library's mission is realized. Librarians are the one group on the campus that knows how to navigate the information networks to locate, filter, and customize information for users. However, we must learn how to look at things differently. We should cultivate the skill to look at functions and services from right to left, upside down, and from back to front. There may be more than two sides to some issues: the optimist looks at the glass as being half full of water, the pessimist views it as half empty, while the environmentalist looks at the quality of the water. Charles Handy believes that "so many things contain their own contradictions, so many good intentions have unintended consequences, and so many formulas for success carry a sting in their tail." ${ }^{2}$

\section{DONALD E. RIGGS}

\section{Notes}

1. Peter F. Drucker, The Effective Executive (New York: Harper \& Row, 1967), 44.

2. Charles Handy, The Age of Paradox (Boston: Harvard Business School Pr., 1994), x. 